\title{
Parole italiane in maschera
}

\section{Italian words in disguise}

Sometimes bioethics uses a vocabulary in disguise [1, 2]. Words "should mean what they mean", instead. This is a trivial statement, but it echoes the truth as defined by Thomas of Aquin: adaequatio rei et intellectus.

There exist words that people prefer to replace with apparently softer expressions: we say "voluntary termination of pregnancy" rather than "abortion", "third age" rather than "old age". In some cases, similar replacements are actual manipulations. Substituting terms with a view to tarnishing the truth has been defined an "anti language" [3].

Curiously enough, there are also inappropriate uses of words that seem to contradict the intentions of those who use them. For example, the young who often change partners and do not clearly support stable emotional and family relationships, often call "fiancé" their occasional, short-term partners.

A curious example of this refers to the debate on advance health care directives or living will. The debate is very heated in Italy. In Italian the "debate on the living will" is usually defined with the expression dibattito sul fine vita. The expression is used both by those who are in favour of the living will and those who oppose it. However, the Italian word "fine" may be masculine (" $i l$ fine") or feminine ("la fine"), with the former meaning "the goal" and the latter "the conclusion": according to the Enciclopedia della filosofia e delle scienze umane " $i$ fine" indicates "in general philosophical sense, the goal to which an action is directed" [4]. The living will concerns the conclusion of life, but in Italian nobody says "sulla fine vita" (feminine): the expression always used is "sul fine vita" (masculine), that is "the goal of life". However, it is certain that nobody considers the living will as "the goal" of life. What is this sort of anti-language due to? The easiest explanation is that it is all about linguistic shabbiness. The rough and simplified use of words is typical of the text-message generation. However, precision is due in bioethics: the fact that, also in the specialised literature, patients, drinkers, passengers and even corpses are all "users" and that technicians, therapists, nurses, physicians, heads of medical wards are all "health care professionals" raises some questions.

Carlo Petrini

Istituto Superiore di Sanità, Presidenza,

Unità di Bioetica.

Via Giano della Bella 34, 00162 Roma

Tel. $(+39) 0649904299$

Fax (+39)0649904303

E-mail: carlo.petrini@iss.it

\section{References}

1. Launer J (2006) Weasel words. QJM 99:353-354

2. Moro A (2006) I confini di Babele. Longanesi, Milano

3. Liverani PG (1993) Dizionario dell'antilingua. Le parole dette per non dire quello che si ha paura di dire. Ares, Milano

4. De Agostini (1996) Enciclopedia della filosofia e delle scienze umane. De Agostini, Novara 